\title{
Evaluating the performance of an internal control system to enhance the quality of auditing Applied research in Al-Muthanna Governorate
}

\author{
${ }^{3}$ Waad Hadi Abd ${ }^{2}$ Akeel Dakheel Kareem, ${ }^{1}$ Hanan A. Kadeem , \\ ${ }^{1}$ Ministry of Higher Education and Scientific Research, ${ }^{2,3} \mathrm{Al}-$ Muthanna University
}

\begin{abstract}
The research aims to evaluate the internal control system's performance to enhance the quality of auditing in economic units. Accordingly, the province of Muthanna was chosen as a sample for the research and the period (2014, 2015. 2016, 2017). The researcher relied on a group of published sources, books, and research on the theoretical side. As for the applied side, a group of methods was relied upon, such as collecting data required from the provincial office and the Financial Supervision Bureau's reports for the years of study. Field observations and visits. As well as personal interviews. The research concluded that no plans had been prepared to draw up the general policy of the governorate and define its priorities in all areas in a way that does not contradict the national development plans, as well as the absence of plans in the field of supervision and control over the functioning of public facilities in the governorate and inspecting them.Consequently, it is necessary to prepare plans to draw up the governorate's general policy and define its priorities in all fields and object to the local council decisions that violate the constitution and laws.
\end{abstract}

Keywords: internal control system, audit, audit quality.

Article Received: 18 October 2020, Revised: 3 November 2020, Accepted: 24 December 2020

\section{Introduction}

To verify the effectiveness and correctness of accounting procedures applied in (Where) it is necessary to follow the most important systems, the internal control system. In recent times, internal control has witnessed a remarkable and essential development because it is an important tool to detect manipulation of public money, fraud, and errors. Internal control is a tool to ensure the application of the accounting procedures used and the best application of general budget. Interest in this system has increased in government units due to a large number of services performed by these units and huge funds that these institutions need in order to achieve the goals set for them through the role that adequate internal control and audit body plays in managing them with the highest level of efficiency and effectiveness and monitoring good management of money used In those offices.

The development in concept of internal control and broadening of its scope and objectives exceeded limits of supervising jobs in accounting and finance departments in service units to include all procedures, means, and methods used in internal organization of these units to achieve the desired goals. The evaluation was conducted in Al-Muthanna Governorate according to rules, standards, and norms adopted in this field, based on explanations, information, and data obtained from the governorate and the information and indicators provided during field visits to departments the governorate.

\section{(Topic One) Research methodology}

First: research problem: research problem can be posed in the form of an unanswered question or several questions, as in the following:

1. Are there deficiencies in the performance of the Muthanna Governorate?

2. Does the internal control system in Al-Muthanna governorate suffer from deficiencies due to a lack of interest in evaluating the internal control system?

Second: the objective of the research: The main objective of research is to evaluate the performance of the Muthanna Governorate and to clarify control problems in this system and what are elements of strength and weakness in it, along with finding suggesting appropriate treatments, as it aims to reach internal control bodies for complete freedom in carrying out their work and following laws and instructions and making decisions.

Third: the importance of research: Because of enormity of funds that the Muthanna Governorate deals with, to preserve these funds, and because of the governorate's need for detailed and 
accurate data, also to facilitate its task in identifying the negative aspects of the internal control system, the importance of need to study and evaluate performance of internal control system emerges.

Fourth: research hypothesis: Based on the research problem, the hypothesis was developed. It is possible to identify strengths and weaknesses, which are as follows: There are deficiencies and weaknesses in performance of the governorate and the performance of internal control system in governorate.

Fifth: Research boundaries: The research is determined spatially over the Muthanna Governorate. As for temporal, the study period is for years $(2014,2015.2016,2017)$.

Sixth: method of study: The researcher relied on a theoretical side on a group of sources, books, and published research. As for applied side, the researcher relied on a set of methods, including:

- Collecting required data from the Governorate Office and reports of the Financial Supervision Bureau for study years.

- Field observations and visits.

- Personal interviews.

Seventh: research structure: The research included an introduction and four topics. The first topic dealt with research methodology. The second topic dealt with theoretical aspect. The third topic was devoted to the applied aspect (an applied study in Al-Muthanna Governorate). The fourth topic dealt with conclusions, recommendations, and a list of sources.

\section{Second topic: Theoretical side}

First: The concept of internal control system:

Internal control is the organizational plan and all means, measures, and procedures prepared by administration to preserve its assets, ensure accuracy of accounting data and degree of reliance on them, and achieving the most significant degree of production efficiency in its operations and commitment to implementing administrative policies set out (Curriculum Design and Development, pg. 45). The system of internal control was defined by the American Institute of Accounting in 1936 as a set of methods and measures adopted by units to protect cash and assets to ensure accuracy of accounting operations documented in books. Internal procedures are carried out by a board of directors of a unit or department and all employees. They are designed to provide reasonable assurance to achieve the following objectives: (Pany, 1998: 218 \& Whittington)

$\checkmark$ Reliance on financial statements.

$\checkmark$ Efficiency and effectiveness of operations.

$\checkmark$ Commitment to implementing laws and legislations.

Second - the importance of internal control system:

The great expansion of economic activities and increase in the size of establishments and their geographical spread led to need for higher management to delegate its powers and responsibilities to different levels within units, which led to needing to provide adequate control to ensure that different administrative levels carry out their duties in accordance with instructions laid down, and thus need for a system appeared internal control aims to assist administration with its functions efficiently and effectively (Curriculum design and development: 45). As well as technological and advanced developments and the emergence of large enterprises with multiple branches and need for the administration to delegate powers and responsibilities to some sub-departments, also need for government agencies to accurate and reliable data and different scope of auditing when transforming from an audit profession to a comprehensive or optional audit. (Yosef et al. 2010: 464).

Third - Objectives of Internal Control System:

From the previous definitions of the internal control system, several objectives emerge. An internal control system imposes physical and accounting protection for all assets from unlawful exploitation, misuse, loss, and embezzlement, whether in bad or good faith. (Zahir, 2005: 90), the objectives of internal control can be clarified as follows (Al-Aajibi, 2016: 2):

1. Supervision: that is, the economic unit administration should establish adequate internal control. Internal auditing exists for a specific responsibility by administration to control and supervise their operations and provide the necessary recommendations.

2. Discovery of intentional or unintentional errors that may be found in books and records.

3. Testing financial, operating, and non-operating information: reviewing means used to define, measure, classify, and report on this financial and non-financial information. 
4. Reducing chances of committing error and fraud, as executor feels that what he is doing will be subject to control and scrutiny.

5. Review compliance with laws, legislation, and other external requirements, administrative policies, directives, and other internal requirements.

As internal control system is subject to obsolescence, it may become with the passage of time and change of circumstances not appropriate, the information needed to conduct evaluation and update comes from various sources, including studying reality of internal control system, internal auditor reports, special reports on monitoring activities and reports by organizations such as agencies concerned with environmental protection and number of cases lost by unit as a result of failure to fulfill its duties towards the environment (Wiley \& Sons, 1997: 249).

\section{Fourth - Elements of internal control system:}

To have an efficient and effective internal control system, it is necessary to prepare components on which this system is based, namely: - (Al-Baaj, 2011: 79).

1. An administrative structure that takes into account in its description sequence of competencies.

2. Detailed procedures for carrying out duties.

3. A sound accounting system that depends on a set of books and records.

4. Selection of competent employees.

5. Monitor performance in project management and its various phases.

\section{Fifth: Types of internal control:}

According to standard (400), the internal control system is divided into the following types: - (Tho-elnon, 2018: 30)

1- Accounting Control: It is a set of control procedures and measures to prevent errors in data, accounting procedures, and regulations. The Audit Standards Committee defined it as the organizational plan and associated procedures and methods to protect assets and ensure accuracy of accounting data used in accounting records.

2. Administrative Control: It includes organizational policies, plans, and records related to administrative decision-making by changing financial operations. These methods aim to increase operating efficiency and develop a spirit of commitment to planning policies, processes, and administrative procedures in the facility. It is concerned with decision-making processes that lead administration to impose its control, authority, and control over these processes.

\section{Sixth - the difference between internal audit and} internal control:

Internal audit is considered a tool of internal control that aims to ensure the accuracy and effectiveness of systems and procedures used and report to management on weaknesses and deviations. The purpose of internal audit is to measure adequacy of internal control systems. (Curriculum design and development: 47).

\section{Seventh - the responsibility of external auditor towards internal control system:}

Establishing an internal control system and maintaining it is the administration's responsibility; the external auditor has nothing to do with its position. An external auditor's function is to study and evaluate the system and determine its strengths and weaknesses. The stronger internal control system, the more the auditor will rely on it, and vice versa.

\section{Eighth- concept and definition of internal audit quality:}

Quality has been defined as the extent of conformity with requirements, as organizations seek to monitor performance, activities, and daily work to reach the highest degree of quality by reducing errors and detecting deviations that lead to meeting management needs. Internal audit quality is based on a good performance of internal control system and extent Adequacy of applied accounting system to reach appropriate effectiveness and efficiency in operations and restrictions, and on an ongoing basis within the organization to serve its objectives and protecting assets. (Al-Abdali, 2012: 34).

Ninth: Audit Quality Objectives:

Auditing quality objectives can be divided into two main groups: (Al-Attar, 2016: 70)

1. The traditional goals and divided into two types

A. Main goals:

Verifying the correctness and accuracy of data recorded in books and the extent of reliance on them.

Express a neutral technical opinion based on strong evidence on extent to which financial statements match financial position.

B. Secondary goals

$\checkmark$ It was discovering errors or fraud that may exist in books and records.

$\checkmark$ It is reducing the chances of committing mistakes and fraud by establishing controls and procedures that prevent this.

$\checkmark$ Management relies on it to determine and draw administrative policies and make decisions, now and in the future. 
$\checkmark \quad 3$. A sound accounting system that depends on a set of books and records.

$\checkmark$ 4. Selection of competent employees.5. Monitor performance in project management and its various phases.

$\checkmark$ Fifth: Types of internal control

$\checkmark$ According to standard (400), the internal control system is divided into the following types: - (Tho-elnon, 2018: 30)

Accounting Control: It is a set of control procedures and measures to prevent errors in data, accounting procedures, and regulations. The Audit Standards Committee defined it as the organizational plan and associated procedures and methods to protect assets and ensure accuracy of accounting data used in accounting records. Administrative Control: It includes organizational policies, plans, and records related to administrative decision-making by changing financial operations. These methods aim to increase operating efficiency and develop a spirit of commitment to planning policies, processes, and administrative procedures in the facility. It is concerned with decision-making processes that lead administration to impose its control, authority, and control over these processes.

Sixth - the difference between internal audit and internal control:

Internal audit is considered a tool of internal control that aims to ensure the accuracy and effectiveness of systems and procedures used and report to management on weaknesses and deviations. The purpose of internal audit is to measure adequacy of internal control systems. (Curriculum design and development: 47).

Seventh - the responsibility of external auditor towards internal control system:

Establishing an internal control system and maintaining it is the administration's responsibility; the external auditor has nothing to do with its position. An external auditor's function is to study and evaluate the system and determine its strengths and weaknesses. The stronger internal control system, the more the auditor will rely on it, and vice versa.

Eighth- concept and definition of internal audit quality:

Quality has been defined as the extent of conformity with requirements, as organizations seek to monitor performance, activities, and daily work to reach the highest degree of quality by reducing errors and detecting deviations that lead to meeting management needs. Internal audit quality is based on a good performance of internal control system and extent Adequacy of applied accounting system to reach appropriate effectiveness and efficiency in operations and restrictions, and on an ongoing basis within the organization to serve its objectives and protecting assets. (Al-Abdali, 2012: 34).

Ninth: Audit Quality Objectives:

Auditing quality objectives can be divided into two main groups: (Al-Attar, 2016: 70)

1. The traditional goals and divided into two types

A. Main goals:

Verifying the correctness and accuracy of data recorded in books and the extent of reliance on them.

Express a neutral technical opinion based on strong evidence on extent to which financial statements match financial position.

B. Secondary goals

$\checkmark$ It was discovering errors or fraud that may exist in books and records.

$\checkmark$ It is reducing the chances of committing mistakes and fraud by establishing controls and procedures that prevent this.

$\checkmark$ Management relies on it to determine and draw administrative policies and make decisions, now and in the future.2. Modern or developing goalsA. Present business results according to set objectives.

B. Monitor plan, follow up on its implementation, the extent of achieving goals, identify deviations, their causes, ways to address them.

C. Achieving maximum possible production efficiency by preventing wastage in all aspects of the activity.

D. Achieving maximum possible well-being for members of society.

\section{Tenth: Elements of Quality Control}

The internal audit profession rises to achieve the highest desired goals. The important thing is that quality is achieved during audit work, as international standards regulating auditing profession in standard (220) recommended the need for institutions to audit according to quality control to ensure the internal audit department serves relevant parties appropriately according to auditing standards. Standard indicated that quality control procedures differ according to the size of institution, nature of its work, or geographical location. Standard indicated that elements of quality control include the following (Al-Tamimi, 2013: 205).

1. Professional requirements: The audit department employees must adhere to rules of professional conduct such as independence, integrity, objectivity, and confidentiality, as well as exert necessary professional care.

2. Efficiency and merit: The audit staff must have a high level of technology and professional competence to fulfill their responsibilities, take the 
necessary care and maintain this high level by continuing education and training.

3. Supervision: There must be adequate direction and supervision and a continuous review of work at all levels to obtain reasonable assurance that all work is carried out to an acceptable level of quality.

4. Inspection: There must be continuous monitoring of the internal audit system's efficiency and effectiveness. The department should inform its employees about those procedures and policies and ensure that they are reasonably aware and understand them.

Eleven: Factors Affecting Internal Audit Quality:

The factors related to the quality of auditing profession are summarized in factors related to audit process, factors related to audit office, and factors related to external parties (Hanan, 2016: 31)

1. Factors related to audit process: These factors include planning audit work, studying and examining internal control system, adequacy of evidence, and report and disclosure.

2. Planning audit work: Planning is necessary to ensure that task is carried out effectively and efficiently and that risks are reduced to an acceptable level.

3. Study and examination of the internal control system and risk assessment: Understanding accounts portfolios for an accounting system and internal control of client is considered to be positively reflected in the audit profession's quality through good planning, controlling audit risks and correcting imbalances to the maximum extent possible.

4. Factors related to audit office: This component focuses on:

A. Independence and impartiality:

B. Academic qualification and professional experience:

\section{The third topic:}

Applied aspect: an applied study in Al-Muthanna Governorate

First: A summarized overview of Muthanna Governorate

The province of Muthanna is located in the southwest of Iraq. Its population is estimated at (808122) people for year 2017; its area is (51740) km2; governorate was established based on the decision of Revolutionary Command Council (dissolved) No. 255 on 06.24.1969 is published in Iraqi newspaper Al-Waqaee No. 1748 in $28 / 6 / 1969$ in the name of (Samawah Brigade), based on Provincial Law No. (159) of 1969, the name was Table (2): Disbursements by the governorate for cleaning up cities changed to (Governorate). The governorate's administrative boundaries were also regulated based on Republic Decree No. (1065) for the year 1989. Finally, the governorate is subject to Law of Governorates not organized in a region No. (21) for year 2008 (amended) and governorate consists of five districts (Samawah, Rumaitha, Al Khader, Warka, and Salman) And seven aspects (Al-Suwair, Al-Darraji, Busayyah, Dignity, Glory, Crescent, Al-Najmi), as it was decided according to the article (122-second) of Iraqi constitution for year 2005 to grant governorates that were not organized in region administrative and financial powers so that they could manage their affairs according to principle Administrative decentralization.

$\underline{\text { Second. Administrative and financial organization }}$

A. The organizational structure and its suitability for the department's activity and objectives.

B. Job Descriptions.

C. Internal control system.

D. Information Systems.

Third. Effect of public policies and external factors on the activity:

1. The state's general budget policies are to grant financial allocations for investment projects to provinces through a program of developing regions and accelerating life to implement the projects necessary to work for various service departments in the province.

2. Law of Second Amendment to Law of Governorates Not Organized in a Region No. 19 of 2013 granted expansion of powers to local authorities and increased financial resources for administrative units to enable them to manage their affairs.

Fifth: general effects of activity on the national economy and community life: -

A. Job and employment opportunities: -

B. The impact of activity on environment: - The governorate seeks to create a healthy environment by supervising the establishment of green areas in various places of governorate by a competent municipality and establishing several projects concerned with the environment and undertakes spending on city cleanings for municipal departments in governorate from sums allocated for cleanups on a budget of Governorate. Table (2) shows an increase in amounts spent during the evaluation years by the maintenance of city cleanings during years (2015 and 2016) and their decrease during year 2017 by $(8 \%)$. 


\begin{tabular}{|l|l|l|}
\hline year & Expense amounts (dinars) & percentage exchange \% \\
\hline $\mathbf{2 0 1 4}$ & 4850463255 & - \\
\hline $\mathbf{2 0 1 5}$ & 6497809427 & 34 \\
\hline $\mathbf{2 0 1 6}$ & 7022657000 & 8 \\
\hline $\mathbf{2 0 1 7}$ & 6429083250 & $(8)$ \\
\hline
\end{tabular}

Source: Prepared by the researcher based on data of Muthanna Governorate

A. size of social benefits: -

The governorate performs compensation transactions for those affected by terrorist operations in accordance with Compensation Law for Victims of Terrorist Operations No. (20) of 2009 through Compensation Subcommittee, and table (3) shows transactions received, completed and not completed during evaluation years, from it following can be seen: - as percentages ranged between $(57 \%$ - 91\%) for years 2014-2015 respectively.

- There was an increase in total amounts paid by the governorate for years $(2014,2015,2016)$ their decrease during year 2017 due to a small number of transactions received during year / 2017, the completion of accumulated transactions during years 2015 and 2016.

- The fluctuation of completion rates of compensation transactions during evaluation years,

Table (3) Transactions received and performed by governorate

\begin{tabular}{|l|l|l|l|l|}
\hline Details & $\mathbf{2 0 1 4}$ & $\mathbf{2 0 1 5}$ & $\mathbf{2 0 1 6}$ & $\mathbf{2 0 1 7}$ \\
\hline Received transactions (1) & 525 & 340 & 229 & 114 \\
\hline Completed transactions (2) & 297 & 249 & 209 & 91 \\
\hline Unfinished transactions (3) & 288 & 91 & 20 & 23 \\
\hline Achievement rate 1/2\% & 57 & 73 & 91 & 80 \\
\hline $\begin{array}{l}\text { Unfinished business 3/1\% } \\
\begin{array}{l}\text { Total amounts of compensation for } \\
\text { completed transactions (dinars) }\end{array}\end{array}$ & 61325000 & 790238958 & 1002985208 & 396847264 \\
\hline
\end{tabular}

Source: Prepared by the researcher based on data of Muthanna Governorate

Eighth: Efficient implementation of plans and policies

Plans, policies, and implementation results:

(1) Ways and methodology for preparing plan:

The study shows it was found that there are no plans to draw general policy of governorate and define its priorities in all areas in a way that does not conflict with national development, supervision and monitoring of operation of public facilities in the governorate and inspecting them, and that drawing up general policies for the governorate and supervising functioning of public utilities are implemented without setting plans.

(1) Data analysis and results:

- Table (4) shows number of decisions taken by the provincial council and notified to governorate, number of decisions that were objected to by governorate, and number of decisions implemented during evaluation 
years, from it appears that implementation rates for decisions of governorate council notified to governorate and in conformity with constitution and laws in force ranged between $(59 \%$ - 95\%) for years 2015 and 2016 respectively, while percentages of decisions objected to by governorate ranged between $(28 \%$ - 5\%) for years 2015 and 2016 respectively, rates of implementation of decisions violating constitution and laws ranged between $(6 \%-13 \%)$ for years 2014,2015 respectively.

Table (4) the decisions by governorate and provincial council

\begin{tabular}{|c|c|c|c|c|c|c|c|}
\hline 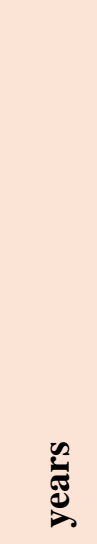 & 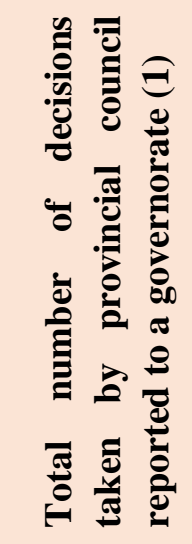 & 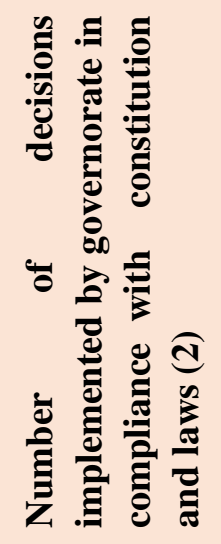 & 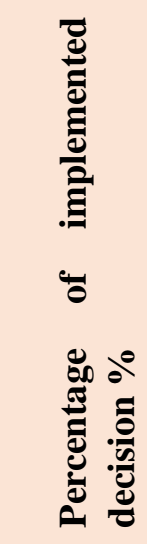 & 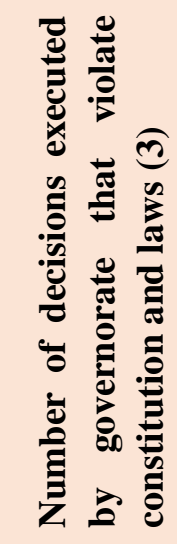 & 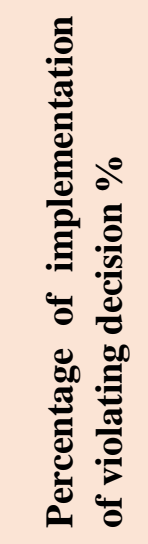 & 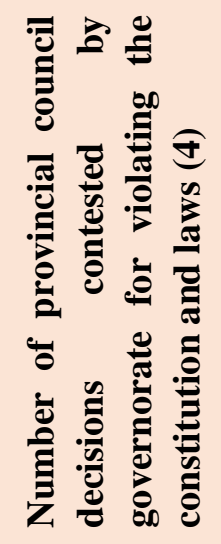 & 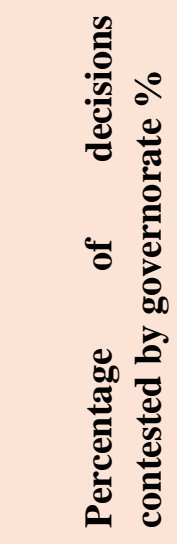 \\
\hline 2014 & 112 & 98 & 88 & 7 & 6 & 7 & 6 \\
\hline 2015 & 32 & 19 & 59 & 4 & 13 & 9 & 28 \\
\hline 2016 & 41 & 39 & 95 & - & - & 2 & 5 \\
\hline 2017 & 71 & 59 & 83 & 5 & 7 & 7 & 10 \\
\hline
\end{tabular}

Source: Prepared by the researcher based on data of Muthanna Governorate

- Table (5) shows the number of conferences, seminars and celebrations that governorate has organized related to governorate affairs and its local administration during evaluation years. The total number of activities undertaken by the governorate in field of conferences, seminars, and celebrations has decreased, as a percentage of change reached (10\%), $(6 \%),(18 \%)$ for years $(2015,2016,2017)$ respectively.

Table (5) conferences, seminars, and celebrations

\begin{tabular}{|l|l|l|l|l|l|}
\hline Years & $\begin{array}{l}\text { Number of } \\
\text { conferences (1) }\end{array}$ & $\begin{array}{l}\text { Number of } \\
\text { seminars (2) }\end{array}$ & $\begin{array}{l}\text { Number of } \\
\text { celebrations (3) }\end{array}$ & Total & $\begin{array}{l}\text { percentage } \\
\text { Change \% }\end{array}$ \\
\hline 2014 & 5 & 8 & 7 & 20 & - \\
\hline 2015 & 7 & 6 & 5 & 18 & $(10)$ \\
\hline 2016 & 4 & 9 & 4 & 17 & $(6)$ \\
\hline 2017 & 4 & 6 & 4 & 14 & $(18)$ \\
\hline
\end{tabular}

Source: Prepared by the researcher based on data of Muthanna Governorate

A. Efficient use of service provision requirements: -

(1) Managing and using human resources

A- Staff: -

1- The governorate appointed deputies, assistants, and advisors to the governor according to the legal article (27) of Law of Governorates Not Organized in a Region No. (21) for the year 2008 (amended), which states (Each governor shall have two deputies with the rank of director- general elected by the council and an order is issued by the governor to appoint them within fifteen days from the date of the Council's election for them). Legal article (33) states (the governor may have the number of assistants for administrative and technical affairs, including no more than five who, carry out tasks entrusted to them by the governor and work under his supervision), article (34) which states (The governorate shall form an advisory body of no more than seven experts that includes employees 
chosen by the governor. Moreover, they shall be specialists in legal, technical, and financial affairs, and as the case requires, they are directly related to the governor and work under his supervision and guidance).

2- Table (6) shows permanent staff in Al-Muthanna Governorate distributed according to the specializations and qualifications, from it is clear that percentage of employees with qualifications (primary or less) has increased from total permanent staff in governorate where the percentage was $(45 \%)$, equivalent to half of the employees within years evaluation respectively. Decrease the percentage of permanent staff in governorate who have technical and administrative diploma qualifications, as percentage reached $(5 \%)$ for all evaluation years.

Table (6) permanent staff in Al-Muthanna Governorate

\begin{tabular}{|c|c|c|c|c|c|c|c|c|}
\hline 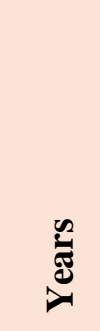 & $\begin{array}{l}\frac{n}{\pi} \\
\frac{\pi}{0}\end{array}$ & 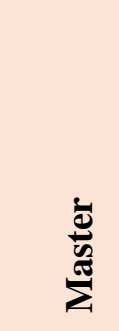 & 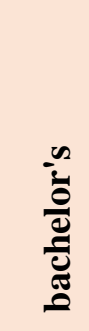 & 莺 & 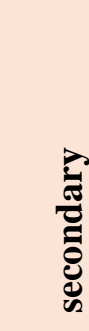 & 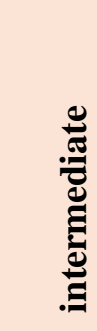 & 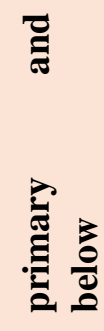 & 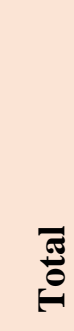 \\
\hline \multirow[t]{2}{*}{2014} & Permanent angel & - & 72 & 15 & 42 & 48 & 148 & 325 \\
\hline & $\begin{array}{l}\text { percentage of total permanents } \\
\text { staff } \%\end{array}$ & - & 22 & 5 & 13 & 15 & 45 & 100 \\
\hline \multirow[t]{2}{*}{2015} & Permanent angel & - & 72 & 15 & 42 & 48 & 148 & 325 \\
\hline & $\begin{array}{l}\text { percentage of total permanents } \\
\text { staff } \%\end{array}$ & - & 22 & 5 & 13 & 15 & 45 & 100 \\
\hline \multirow[t]{2}{*}{2016} & Permanent angel & 2 & 77 & 20 & 53 & 54 & 163 & 369 \\
\hline & $\begin{array}{l}\text { percentage of total permanents } \\
\text { staff } \%\end{array}$ & $\begin{array}{l}\text { Less } \\
\text { than } 1\end{array}$ & 21 & 5 & 14 & 15 & 45 & 100 \\
\hline \multirow[t]{2}{*}{2017} & Permanent angel & 2 & 77 & 20 & 53 & 54 & 163 & 369 \\
\hline & $\begin{array}{l}\text { percentage of total permanents } \\
\text { staff } \%\end{array}$ & $\begin{array}{l}\text { Less } \\
\text { than } 1\end{array}$ & 21 & 5 & 14 & 15 & 45 & 100 \\
\hline
\end{tabular}

Source: Prepared by the researcher based on data of Muthanna Governorate

3- As for table (7), certified permanent staff is occupied during evaluation years, we notice in it there is a shortage of the occupied permanent staff from certified staff during evaluation years, as a percentage of unfilled staff to certified ranged between $(7 \%-22 \%)$ during evaluation years.

Table (7) unfilled certified staffs

\begin{tabular}{|l|l|l|l|l|l|}
\hline Years & certified staffs (1) & Unfilled staffs (2) & $\mathbf{=}(\mathbf{1 - 2})$ unfilled & $\begin{array}{l}\text { unfilled } \\
\mathbf{( 1 / 3 )} \%\end{array}$ & percentage \\
\hline 2014 & 348 & 325 & 23 & 7 \\
\hline 2015 & 415 & 325 & 90 & 22 \\
\hline 2016 & 418 & 369 & 49 & 12 \\
\hline 2017 & 418 & 369 & 49 & 12 \\
\hline
\end{tabular}


Source: Prepared by the researcher based on data of Muthanna Governorate

B. training and development:-

The governorate trained its affiliates and involved them in several training courses inside and outside Iraq. Table (8) shows the number of courses held and preparing associates participating in those courses during evaluation years in the governorate as follows: -

- The governorate did not prepare a plan to train and develop the employees indicating the titles of the required courses and specializations and the number of employees whose training required inside and outside Iraq for all the evaluation years.

- Decrease in the participation rate in training courses inside Iraq during evaluation years, as it reached $(22 \%, 17 \%, 6 \%)$, except for year 2015 , which increased to (32\%) of total permanent staff.

- The decrease in rates of change in numbers of training courses and the number of participants inside and outside Iraq during years 2016 and 2017.

Table (8) Training courses inside and outside Iraq

\begin{tabular}{|c|c|c|c|c|c|c|c|}
\hline \multirow[b]{2}{*}{ Years } & \multirow[b]{2}{*}{ Details } & \multirow{2}{*}{$\begin{array}{l}\text { Courses } \\
\text { number }\end{array}$} & \multirow{2}{*}{$\begin{array}{l}\text { number of } \\
\text { participants }\end{array}$} & \multicolumn{2}{|c|}{ percentage change $\%$} & \multirow{2}{*}{$\begin{array}{l}\text { permanent } \\
\text { staffs }\end{array}$} & \multirow{2}{*}{$\begin{array}{l}\text { Percentage } \\
\text { of } \\
\text { participants } \\
\text { to } \\
\text { permanent } \\
\text { staff \% }\end{array}$} \\
\hline & & & & $\begin{array}{l}\text { Courses } \\
\text { number }\end{array}$ & $\begin{array}{l}\text { Courses } \\
\text { number }\end{array}$ & & \\
\hline \multirow{2}{*}{2014} & $\begin{array}{l}\text { Courses inside } \\
\text { Iraq }\end{array}$ & 29 & 70 & - & - & \multirow{2}{*}{325} & 22 \\
\hline & $\begin{array}{l}\text { Courses } \\
\text { outside Iraq }\end{array}$ & 4 & 4 & - & - & & 1 \\
\hline \multirow{2}{*}{2015} & $\begin{array}{l}\text { Courses inside } \\
\text { Iraq }\end{array}$ & 34 & 105 & 17 & 50 & \multirow{2}{*}{325} & 32 \\
\hline & $\begin{array}{l}\text { Courses } \\
\text { outside Iraq }\end{array}$ & 19 & 47 & 375 & 1075 & & 14 \\
\hline \multirow{2}{*}{2016} & $\begin{array}{l}\text { Courses inside } \\
\text { Iraq }\end{array}$ & 24 & 61 & (29) & (42) & \multirow{2}{*}{369} & 17 \\
\hline & $\begin{array}{l}\text { Courses } \\
\text { outside Iraq }\end{array}$ & 6 & 17 & (68) & (64) & & 5 \\
\hline \multirow{2}{*}{2017} & $\begin{array}{l}\text { Courses inside } \\
\text { Iraq }\end{array}$ & 14 & 23 & (42) & (62) & \multirow{2}{*}{369} & 6 \\
\hline & $\begin{array}{l}\text { Courses } \\
\text { outside Iraq }\end{array}$ & 29 & 70 & - & - & & 22 \\
\hline
\end{tabular}

Source: Prepared by the researcher based on data of Muthanna Governorate

C. incentive system: -

The absence of a unique incentive system for the governorate has granted incentive bonuses to workers instead. Table (9) shows the total number of employees Table (9) Total number of employees and bonuses working in governorate and total incentive rewards amounts for current and investment budgets; we notice fluctuation of rates of change in bonus amounts granted during evaluation years, which increased by (25) \% During year 2015 and decreased by (47\%) during year 2017.

\begin{tabular}{|l|l|l|} 
Years & $\begin{array}{l}\text { Total number of employees in } \\
\text { governorate (1) }\end{array}$ & $\begin{array}{l}\text { Incentive reward amount } \\
\text { (dinar) (2) }\end{array}$ \\
\hline
\end{tabular}

percentage change $\%$ 


\begin{tabular}{|l|l|l|l|}
\hline 2014 & 655 & 913793000 & - \\
\hline 2015 & 282 & 1146456700 & 25 \\
\hline 2016 & 951 & 1184974800 & 3 \\
\hline 2017 & 906 & 623950000 & $(47)$ \\
\hline
\end{tabular}

Source: Prepared by the researcher based on data of Muthanna Governorate

(2) Management and use of financial resources A. Implementing current budget for governorate's expenditures: -

Table (10) shows the results of implementing a current budget for governorate's expenditures during evaluation years, as follows: -

- An increase in spending implementation, reaching $(75 \%, 90 \%$, and $91 \%)$ for years

\begin{tabular}{|l|l|l|l|l|}
\hline Years & $\begin{array}{l}\text { Actual Expense / Dinar } \\
\text { (1) }\end{array}$ & $\begin{array}{l}\text { percentage } \\
\text { change \% }\end{array}$ & $\begin{array}{l}\text { Annual Allocation / Dinar } \\
\text { (2) }\end{array}$ & $\begin{array}{l}\text { Execution } \\
\text { percentage \% (1/2) }\end{array}$ \\
\hline 2014 & 12595291467 & - & 16868208024 & 75 \\
\hline 2015 & 16141304180 & 28 & 18020128750 & 90 \\
\hline 2016 & 18297880186 & 13 & 20171196480 & 91 \\
\hline 2017 & 24001306754 & $(23)$ & 15386051379 & 91 \\
\hline
\end{tabular}

Source: Prepared by the researcher based on data of Muthanna Governorate

B. Implementation of the current budget of governorate's revenues: -

Table (11) shows results of implementing current budget for the governorate's revenues during evaluation years; from analysis of following table is clear:

- Increase in percentage change of actual total revenues during year 2015 compared to year 2014

\begin{tabular}{|l|l|l|l|l|}
\hline Years & $\begin{array}{l}\text { Actual revenue / Million } \\
\text { Dinar (1) }\end{array}$ & $\begin{array}{l}\text { percentage } \\
\text { change \% }\end{array}$ & $\begin{array}{l}\text { Estimated Revenue / } \\
\text { Million dinars (2) }\end{array}$ & $\begin{array}{l}\text { Execution } \\
\text { percentage \% (1/2) }\end{array}$ \\
\hline 2014 & 741 & - & 1278 & 58 \\
\hline 2015 & 2980 & 302 & 3120 & 96 \\
\hline 2016 & 1203 & $(60)$ & 2100 & 57 \\
\hline 2017 & 1179 & $(2)$ & 2000 & 58 \\
\hline
\end{tabular}

(2014/2015/2016) respectively, while it has not changed for the year 2017.

- the high percentage of change in governorate's expenditures for years 2015 and 2016, reaching (28\% and $13 \%$ ), respectively, as a result of increase in governorate's allocations, while there was a decrease in percentage change in governorate's expenditures for year 2017 compared to year 2016, reaching (23\%).

Table (10) Results of implementing current budget for governorate's expenditures

by $(302 \%)$, while there was a decrease in the percentage of change for years 2016 and 2017, reaching (60\% and $2 \%)$ respectively.

- Low implementation ratios of actual to estimated revenues during years 2014, 2016, and 2017 reaching $(58 \%, 57 \%$, and 58\%) respectively, as for year 2015 it increased to (96\%).

Table (11) Results of implementing current budget for governorate's revenues 
Source: Prepared by the researcher based on data of Muthanna Governorate

C. Implementation of investment budget (ratios of appropriation utilization): -

Table (12) shows results of implementing investment budget for governorate during evaluation years, through it the following is evident: -

- Fluctuation rate of implementation of investment projects for the province during evaluation years, reaching $(100 \%, 73 \%, 74 \%, 99 \%)$ respectively• High rates of change in investment project expenditures during years 2015 and 2016, reaching (52\% and 39\%), respectively, and a decrease in percentage change during 2017, which amounted to (32\%) compared to 2016.

- Actual expenditures of investment projects for governorate exceeded amounts funded to them (2014, 2016, and 2017). As implementation ratios reached $(117 \%, 108 \%$, and $125 \%)$, the revolved cash balance was used to cover expenditures above the amounts funded.

Table (12) Results of implementing investment budget for the province

\begin{tabular}{|c|c|c|c|c|c|c|c|}
\hline \multirow{2}{*}{ Years } & \multirow{2}{*}{$\begin{array}{l}\text { Actual } \\
\text { expenses } \\
\text { Million Dinar } \\
\text { (1) }\end{array}$} & \multirow{2}{*}{$\begin{array}{l}\text { Execution } \\
\text { percentage } \\
\%(1 / 2)\end{array}$} & \multirow{2}{*}{$\begin{array}{l}\text { Customizations } \\
\text { Million Dinar (2) }\end{array}$} & \multirow{2}{*}{$\begin{array}{l}\text { Financing } \\
\text { Millions } \\
\text { Dinar (3) }\end{array}$} & \multicolumn{3}{|c|}{ rate $\%$} \\
\hline & & & & & $1 / 2$ & $1 / 3$ & $2 / 3$ \\
\hline 2014 & 91356 & - & 91565 & 78221 & 100 & 117 & 85 \\
\hline 2015 & 138861 & 52 & 190748 & 162649 & 73 & 85 & 85 \\
\hline 2016 & 192855 & 39 & 260625 & 178645 & 74 & 108 & 69 \\
\hline 2017 & 120630 & (37) & 122115 & 96433 & 99 & 125 & 79 \\
\hline
\end{tabular}

Source: Prepared by the researcher based on data of Muthanna Governorate

D. Completed projects and their contribution to realization of activity: -

1- Table (13) shows the number of investment projects planned and implemented in Al-Muthanna Governorate during evaluation years; the table shows the following:

- There is a decrease in the percentage of number of completed projects to plan during evaluation years, as it reached $(46 \%, 45 \%, 62 \%$, and $74 \%)$ respectively.
- An increasing percentage of implemented projects to many planned projects during evaluation years, reaching $(87 \%, 90 \%, 90 \%$, and 95\%) respectively.

- A decrease in the financial completion percentage of investment projects for years (2015 and 2016), as percentages reached (73\% and $74 \%)$ respectively.

- The low percentage of total projects' material achievement during evaluation years reached $(65 \%, 39 \%, 36 \%$, and $76 \%)$ for evaluation years, respectively.

Table (13) Investment projects planned and implemented in the province

\begin{tabular}{|l|l|l|l|l|}
\hline Evaluation year & $\mathbf{2 0 1 4}$ & $\mathbf{2 0 1 5}$ & $\mathbf{2 0 1 6}$ & $\mathbf{2 0 1 7}$ \\
\hline Planned Projects (1) & 363 & 694 & 830 & 830 \\
\hline Completed Projects (2) & 166 & 312 & 516 & 614 \\
\hline Projects in Progress (3) & 151 & 310 & 233 & 176 \\
\hline Total 2+3 (4) & 317 & 622 & 749 & 790 \\
\hline
\end{tabular}




\begin{tabular}{|l|l|l|l|l|}
\hline Ratio (1/2)\% & 46 & 45 & 62 & 74 \\
\hline Ratio (1/4)\% & 87 & 90 & 90 & 95 \\
\hline Financial achievement percentage & 100 & 73 & 74 & 99 \\
\hline
\end{tabular}

Source: Prepared by the researcher based on data of Muthanna Governorate

2- As for table (14), it is clear that percentage of number of lagging projects has increased to total number of continuous projects during evaluation years, reaching $(56 \%, 52 \%, 72 \%$, and $32 \%)$ respectively, as follows: -

Table (14) Continuing and lagging projects in the province

\begin{tabular}{|l|l|l|l|}
\hline Years & $\begin{array}{l}\text { Number of continuing } \\
\text { projects (1) }\end{array}$ & $\begin{array}{l}\text { Number of lagging } \\
\text { projects (2) }\end{array}$ & percentage \% (1/2) \\
\hline 2014 & 151 & 84 & 56 \\
\hline 2015 & 310 & 160 & 52 \\
\hline 2016 & 233 & 168 & 72 \\
\hline 2017 & 176 & 57 & 32 \\
\hline
\end{tabular}

Source: Prepared by the researcher based on data of Muthanna Governorate

3- No data were obtained about the amounts allocated. A number of projects were implemented on petrodollar allocations during evaluation years, while data were obtained about amounts disbursed only since these allocations are added to regional development projects plan. There is no independent plan for it; therefore, there is no statistic about amounts allocated and number of projects implemented. Table (15) shows that the governorate did not grant allocations to petrodollar projects during year 2014. It also decreased allocations for petrodollar projects to governorate during year 2016 compared to year 2015 by (27\%), and then increase in percentage of change in year 2017 to $50 \%$.

Table (15) Petrodollar allocations

\begin{tabular}{|l|l|l|}
\hline Year & Amount allocated / Million Dinar & percentage change \% \\
\hline 2014 & 0 & - \\
\hline 2015 & 7722 & \\
\hline 2016 & 5667 & $(27)$ \\
\hline 2017 & 8522 & 50 \\
\hline
\end{tabular}

Source: Prepared by the researcher based on data of Muthanna Governorate

E. Governorate property: -

1. Table (16) shows total property of governorate and actual revenues during evaluation years. From the analysis of table, the following is clear:-

- Volume of revenues generated from real estate belonging to the governorate is not commensurate with its number, location, and contribution to the governorate's economic life.
- Low percentage of change in revenues generated from the rent of governorate's properties during evaluation years, as it reached ( $21 \%$ and $10 \%)$ for years 2015 and 2017 respectively, and decreased by (3\%) during year 2016.

- Failure of governorate to maintain its properties and take the necessary measures to determine damages that affect shops, apartments, and residential homes belonging to them during evaluation years.

Table (16) Total property of the province and actual revenues 


\begin{tabular}{|l|l|l|l|}
\hline Year & Number of property & $\begin{array}{l}\text { Achieved } \\
\text { (Dinar) }\end{array}$ & Revenue \\
\hline 2014 & 510 & 382991645 & - \\
\hline 2015 & 510 & 462553792 & 21 \\
\hline 2016 & 510 & 448324669 & $(3)$ \\
\hline 2017 & 511 & 492290937 & 10 \\
\hline
\end{tabular}

Source: Prepared by the researcher based on data of Muthanna Governorate

2- Table (17) shows a number of properties in AlMuthanna Governorate that are exploited, unexploited, and exceeded during evaluation years, where we can note the following: -

- The governorate did not take necessary measures concerning properties exceeded. It was noted that

\begin{tabular}{|c|c|c|c|c|c|}
\hline Year & property type & $\begin{array}{l}\text { Total } \\
\text { number } \\
\text { (1) }\end{array}$ & unexploited (3) & $\begin{array}{l}\text { Surpassed } \\
\text { (4) }\end{array}$ & $\begin{array}{l}\text { Percentage } \\
\text { Surpassed } \\
\%(1 / 4)\end{array}$ \\
\hline \multirow{5}{*}{2014} & Lands & 9 & 9 & 2 & 22 \\
\hline & Shops & 189 & 2 & 2 & 1 \\
\hline & Residential homes and apartments & 290 & 2 & 1 & 0.3 \\
\hline & Public buildings and garages & 22 & 3 & - & - \\
\hline & Total & 510 & 16 & 5 & 1 \\
\hline \multirow{5}{*}{2015} & Lands & 9 & 9 & 2 & 22 \\
\hline & Shops & 189 & 2 & 2 & 1 \\
\hline & Residential homes and apartments & 290 & 2 & - & - \\
\hline & Public buildings and garages & 22 & 3 & - & - \\
\hline & Total & 510 & 16 & 4 & 1 \\
\hline \multirow{5}{*}{2016} & Lands & 9 & 9 & 2 & 22 \\
\hline & Shops & 189 & 2 & 2 & 1 \\
\hline & Residential homes and apartments & 290 & 2 & 1 & 0.3 \\
\hline & Public buildings and garages & 22 & 3 & - & - \\
\hline & Total & 510 & 16 & 5 & 1 \\
\hline 2017 & Lands & 9 & 9 & 2 & 22 \\
\hline
\end{tabular}

their number remained constant during years of evaluation, the governorate filing lawsuit against transgressors, the follow-up is continued by governorate.

- Necessary measures were not taken to benefit from unused real estate during evaluation years.

Table (17) the exploited, unexploited, and surpassed property of the governorate 


\begin{tabular}{|l|l|l|l|l|l|}
\hline Shops & 189 & 2 & 2 & 1 \\
\hline Residential homes and apartments & 290 & 2 & 1 & - \\
\hline \begin{tabular}{l|l|l|l|} 
Public buildings and garages \\
Total
\end{tabular} & 23 & 4 & 1 & 4 \\
\hline
\end{tabular}

Source: Prepared by the researcher based on data of Muthanna Governorate

3- The governorate manages the quarries that fall within its administrative boundaries by leasing them to investors in accordance with Mineral Investment Regulation Law No. 1 of 1988 (amended) by coordinating with the General Authority for Geological Survey to define quarrying sites and their borders and implement procedures stipulated in Quarries Instructions No. 1) for year 1989 to regulate investment contracts with investors. Table (18) shows number and types of invested quarries during evaluation years and amounts of revenues generated from them. We note from that table the following:

$\checkmark$ The governorate does not have an integrated information base on quarries or places that could

\begin{tabular}{|l|l|l|l|l|l|}
\hline \multirow{2}{*}{ Statement } & \multicolumn{2}{l|}{ Number of invested quarries } \\
\cline { 2 - 5 } & 2014 & 2015 & 2016 & 2017 \\
\hline Clay bricks & 18 & 11 & 29 & 43 \\
\hline Raw pebbles & 6 & 2 & 3 & 8 \\
\hline burial soil & 1 & 2 & 1 & 2 \\
\hline sand & 2 & 1 & - & 3 \\
\hline Secondary gypsum & 3 & 5 & 3 & 8 \\
\hline Cement clays & 1 & 2 & 2 & 1 \\
\hline Stones & 1 & 5 & 7 & 6 \\
\hline Total & 32 & 28 & 45 & 71 \\
\hline The annual revenue received. million dinar & 290 & 268 & 569 & 613 \\
\hline
\end{tabular}

be invested as a quarry. We notice an increase in the number of quarries annually without explaining reasons for not exploiting these quarries previously or whether others exploit them.

$\checkmark$ A decrease in revenues generated from rent of quarries in governorate during year 2015 amounted to (268) million dinars compared to year 2014, which amounted to (290) million dinars.

$\checkmark$ The number of quarries in the governorate fluctuated during evaluation years; the largest number of these quarries during year 2017 reached (71) quarries while decreasing to (28) quarries during 2015.

Table (18) Number of quarries and amounts of revenue generated
Source: Prepared by the researcher based on data of Muthanna Governorate 
- Increase percentage of change in amounts of debts to the Governorate during year 2015 by $(61 \%)$ and its decrease by (44\%) and (17\%) for years 2016 and 2017.
- The governorate did not make the necessary efforts to collect amounts of debts owed by tenants and follow-up and control their properties' revenues.

Table (19) Unrecovered debt

\begin{tabular}{|l|l|l|}
\hline Year & Amount debt as of 12.31 (Dinar) & Percentage change \% \\
\hline 2014 & 49580700 & - \\
\hline 2015 & 79600000 & 61 \\
\hline 2016 & 44600000 & $(44)$ \\
\hline 2017 & 36800000 & $(170$ \\
\hline
\end{tabular}

Source: Prepared by the researcher based on data of Muthanna Governorate

\section{(3) Use of assets}

A- Fixed assets: -

1- Table (20) shows the acquisition of fixed assets in the governorate and through it increase percentage of Table (20) Fixed assets

\begin{tabular}{|l|l|l|}
\hline Year & Non-financial assets / thousand dinars & Percentage change \% \\
\hline 2014 & 1028120950 & - \\
\hline 2015 & 3371294150 & 288 \\
\hline 2016 & 1392842250 & $(59)$ \\
\hline 2017 & 527991500 & $(62)$ \\
\hline
\end{tabular}

change in acquisition of fixed assets during year (2015) amounting to $228 \%$ from previous year, while there was a decrease in percentage of change during evaluation years (2016 and 2017), which amounted to ( 59\%), $(62 \%)$ respectively.
Source: Prepared by the researcher based on data of Muthanna Governorate

2- Table (21) shows amounts disbursed by the maintenance of fixed assets maintenance. From this table, it is clear that rates of change of amounts spent on maintaining fixed assets have fluctuated, reaching the highest percentage of 164\% for year 2016 and the lowest percentage (50\%) for year 2017 .

Table (21) Amounts disbursed for maintenance of fixed assets

\begin{tabular}{|l|l|l|}
\hline Year & Maintenance amounts / million dinars & \multirow{2}{*}{ Percentage change \% } \\
\hline 2014 & 884565870 & $(28)$ \\
\hline 2015 & 635500250 & 164 \\
\hline 2016 & 1677368775 & $(50)$ \\
\hline 2017 & 837344125 & \\
\hline
\end{tabular}

Source: Prepared by the researcher based on data of Muthanna Governorate

B- Transportation methods: - 
1- Table (22) shows a number of transportation modes available to the governorate during evaluation years; from it, we can see: -

- The governorate used cars of some other departments in governorate through their placement to work in governorate, where their numbers ranged between (19-21) cars during evaluation years despite the high number of cars in governorate relative to work with other agencies, as they ranged between (0-32) cars during evaluation years.

- Increase in percentage change in number of transportation modes in governorate during years (2015 and 2016), which amounted to (4\% and $13 \%)$ respectively. However, it decreased by (13\%) during year 2017 due to the governorate donating cars to Muthanna Governorate Council. Table (22) Number of transportation methods in the province

\begin{tabular}{|c|c|c|c|c|c|c|}
\hline \multirow{2}{*}{ Year } & \multicolumn{2}{|c|}{ transportation methods } & \multirow{2}{*}{ Total } & \multirow{2}{*}{$\begin{array}{l}\text { Percentage } \\
\text { change \% }\end{array}$} & \multirow{2}{*}{$\begin{array}{l}\text { Cars attributed from } \\
\text { the province to other } \\
\text { departments }\end{array}$} & \multirow{2}{*}{$\begin{array}{lr}\text { Cars } & \text { attributed } \\
\text { from } & \text { other } \\
\text { departments } & \text { to } \\
\text { province } & \end{array}$} \\
\hline & Valid & $\begin{array}{ll}\text { out } & \text { of } \\
\text { work } & \end{array}$ & & & & \\
\hline 2014 & 120 & - & 120 & 0 & 32 & 21 \\
\hline 2015 & 123 & 2 & 125 & 4 & 31 & 20 \\
\hline 2016 & 139 & 2 & 141 & 13 & 24 & 21 \\
\hline 2017 & 120 & 3 & 123 & (13) & 0 & 19 \\
\hline
\end{tabular}

Source: Prepared by the researcher based on data of Muthanna Governorate

2- An increase in amounts which spent annually on the maintenance of transportation means during the years 2015 and 2016 by (33\% and 46\%) respectively, while decreased during year 2017 by (18\%) due to decrease percentage of change in number of transport modes during year 2017 as shown in table (23) below: -

Table (23) Car maintenance amounts

\begin{tabular}{|l|l|l|}
\hline Year & Maintenance amounts/dinars & Percentage change \% \\
\hline 2014 & 144821750 & \\
\hline 2015 & 19330750 & 33 \\
\hline 2016 & 282231000 & 46 \\
\hline 2017 & 230130000 & $(18)$ \\
\hline
\end{tabular}

Source: Prepared by the researcher based on data of Muthanna Governorate

3. Absence of a system for periodic inspection and maintenance of means of transport for the governorate during evaluation years.

4.Table (24) shows a number of methods of transport and the number of drivers during evaluation years;

\begin{tabular}{|l|l|l|l|}
\hline Year & Valid Transport Methods (1) & Drivers number (2) & Percentage 2/1 \% \\
\hline 2014 & 120 & 35 & 29 \\
\hline 2015 & 125 & 38 & 30 \\
\hline
\end{tabular}

it is clear that number of employees from drivers in the governorate has decreased in relation to the number of cars during evaluation years, as percentages ranged between $(29 \%-36 \%)$ for years 2014 and 2017 respectively.

Table (24) Methods of transport and drivers number 


\begin{tabular}{|l|l|l|l|}
\hline 2016 & 141 & 42 & 30 \\
\hline 2017 & 123 & 44 & 36 \\
\hline
\end{tabular}

Source: Prepared by the researcher based on data of Muthanna Governorate

C- Libraries: As of December 31, 2017, the number of public libraries in Al-Muthanna Governorate reached

\begin{tabular}{|l|l|l|}
\hline Administrative unit & Books number \\
\hline Rumaitha District & 1905 \\
\hline AL-Khidhir District & 312 \\
\hline
\end{tabular}

(two) distributed among (two administrative units) out of (eleven) administrative units affiliated to Governorate of Al-Muthanna as follows:

Table (25) Libraries in the province
Source: Prepared by the researcher based on data of Muthanna Governorate

\section{Notes on libraries are as follows:}

- Limited number of books available in libraries, and their lack of development during evaluation years.

- The number of administrative units that do not have libraries (9) reached nine administrative units, which constitute $(82 \%)$ of the total number of administrative units affiliated to it.

- Despite the increased need for public libraries due to the increase in population, the governorate does not have plans to build new libraries in all administrative units that are not available in them except for the Samawah district, where a contract was signed on a project to establish a public library in Samawah during the year 2013. However, this project was not completed to date.

The fourth topic:

\section{Conclusions and recommendations}

\section{First: conclusions}

Based on what was stated in the report as mentioned above, it can be said that the governorate has not achieved all tasks which were mentioned in the Governorates Law that are not organized in Region No. 21 of 2008 (amended). The following are the most important conclusions obtained:

1. No plans have been prepared to draw up the governorate's general policy and define its priorities in all areas that do not contradict national development plans and the absence of plans in supervision and control over public facilities' functioning in the governorate.
2. The governorate's implementation of some local council decisions that violate the constitution and laws.

3. Lack of libraries in most administrative units of governorate, a small number of books in available libraries, and the lack of development of their numbers during evaluation years.

4. The province should prepare an updated organizational structure according to governorate law variables, but it has not been approved by governorate.

5. The governorate did not maintain its properties and took necessary measures to determine damage to shops, apartments, and residential homes belonging to them.

6. There is no complete database of quarries or places that can be invested as quarries.

7. The governorate uses cars attributed to it from some departments to increase the number of governorate's cars related to work to other departments.

8. A decrease in the number of employees from the drivers in relation to the number of cars.

9. The percentage of completed projects to planned decreases, reaching $(46 \%, 45 \%, 62 \%$, and $74 \%)$ for years $(2014,2015,2016$, and 2017).

10. Increase in the percentage of stalled projects to the total number of continuing projects, reaching $(56 \%, 52 \%, 72 \%$, and $32 \%)$ for years $(2014$, 2015,2016 , and 2017) respectively.

11. Absence of a plan for appointment to vacant ranks within a business strategy and in accordance with specific principles and standards.

12. A staff training and development plan has not been prepared, indicating titles of required courses and specializations and the number of employees whose training is required inside and outside Iraq. 
13. There is no written and clear mechanism for dividing work among employees and specifying each employee's duties and responsibilities to organize work and avoid obstacles facing implementation and contribute to raising efficiency, economic, and effectiveness.

14. Failure to use modern technology in storing, classifying, and displaying data for various governorate activities.

15. Low implementation rates for actual revenues to estimate during evaluation years.

16. Rounded cash balance covers expenditures that exceed amounts funded for investment projects during years $(2014,2016$, and 2017).

17. Low percentage of change in revenues generated from governorate's property rent during evaluation years.

18. The weakness of governorate's procedures in collecting debts owed by tenants for their properties and necessary measures have not been taken regarding overrun property and the use of new properties.

Second: Recommendations

1- Necessity to prepare plans to draw up the governorate's general policy and define its priorities in all areas.

2- Objection to local council decisions that violate the constitution and laws.

3- Necessity to provide libraries in administrative units is not available and increases books in available libraries.

4- Work to approve the governorate's updated organizational structure according to changes in the (amended) Governorates Law.

5- The necessity of working on the maintenance of the property and limiting and remedying damages that affect shops, apartments, and houses

6- Working on preparing an integrated database of quarries or places that could be invested as quarries.

7- Terminate the placement of governorate cars that are related to work with other departments and vice versa.

8- Work to increase the number of employees from drivers in proportion to number of cars.

9- Necessity of working to increase the number of completed projects to plan.

10- Necessity to take necessary measures regarding delayed projects.

11- Preparing a plan for appointment to vacant ranks within a business strategy and in accordance with specific principles and standards.

12- Preparing a staff training and development plan indicating titles of required courses and specializations and number of employees whose training is required inside and outside Iraq.

13- Preparing a written and clear mechanism for dividing work among employees and defining each employee's duties and responsibilities.

14- Making use of modern technology in storing, classifying, and displaying data for the governorate's various activities.

15- Necessity to work on increasing the revenue realization ratio of actual revenues to estimated.

16- Work to provide the necessary financing for investment projects and not use revolving cash balance to cover expenditures that exceed amounts funded.

17- Work to increase revenues generated from the governorate's property rent.

18- Working on collecting debts owed by tenants of governorate's properties, using unused properties, and taking necessary measures regarding the overrun property.

\section{References}

1- Al-Aajibi, A. D. Karim, The role of internal auditing in raising institutions' performance and improving the environment, and applied study in an environmental department, published research, 2016.

2- Al-Abdali, M. A. Hammed, The Effect of Applying Corporate Governance on the Quality of Internal Auditing in Industrial Companies Listed on the Kuwait Stock Exchange, Middle East University - College of Business, 2012.

3- Al-Attar, H. A. Abd, The Impact of the Quality of Internal Auditing on Efficiency of Implementing Investment Budget Projects in Young Iraqi Universities, Case Study at Muthanna University and Maysan, Published Research, Al-Muthanna Journal of Administrative and Economic Sciences, Volume 6, Issue 2, 2016.

4- Al-Baaj, Q. M. Abdullah, Evaluation of Internal Control Systems in Higher Education Sector Units an Applied Study in Department of Internal Control and Audit, published research, Al-Qadisiyah Journal of Administrative and Economic Sciences Volume 13 - Issue 4, 2011.

5- Al-Hasany, W. H. Abd, External Control and Its Impact on Evaluating Internal Control Performance, Published Research, AlMuthanna University, 2016.

6- Al-Tamimi, J. Handal, Factors Affecting the Quality of Audit Process, a Field Study in Colleges and Research Centers at Basra University, Published Research, 2013. 
7- Hanan, Belkhadem, The Impact of Internal Audit Quality on Corporate Governance, Case Study of Al-Zayban Al-Qantara Mills, Algeria, Mohamed Khaider University of Biskra Faculty of Economic Sciences and Management Sciences, 2016.

8- John Wiley \& Sons, 1998, Practical_Pollution_Prevention_ActivityBased Costing for EHS, pollution Prevention Review.

9- Rifat, F. Ihsan, Internal Control System in Nineveh Agriculture Directorate, research to Arab Institute for Legal Accountancy, 2007

10- The General Administration for Curriculum Design and Development, Accounting / Review and Internal Control / 247 According, General Organization for Vocational Education, Kingdom of Saudi Arabia.

11- Tho-elnon, M. Al-Adawi, The Effect of Internal Control System on Efficiency of Auditing with Statistical Samples, A Case Study of National Audit Bureau, Neelain University, 2018.

12- Whittington, O. Ray, Pany, Kurt, 1998, Principles of Auditing 12th edition, MccrawHill Calnc, New York.

13- Yousef, H. Yousef, and others, Auditing (2), Damascus University Publications - 2010. 